\title{
FAECAL PROTEINASES OF THE FUNGUS-GROWING ANT, ATTA TEXANA: PROPERTIES, SIGNIFICANCE AND POSSIBLE ORIGIN
}

\author{
NORMAN D. BOYD and MICHAEL M. MARTIN \\ The Departments of Chemistry and Zoology, University of Michigan, Ann Arbor, \\ Michigan 48104, U.S.A.
}

(Received 24 Fanuary 1975)

\begin{abstract}
The proteolytic activity previously reported in the faecal fluid of fungus-growing ants is due to the presence of three enzymes. These enzymes have been partially purified and characterized. One is a serine proteinase; the other two are metalloendopeptidases. The physical and catalytic properties of the enzymes reflect their adaptive role in the ants' fungus-culturing activities, and also suggest that they are of microbial origin.
\end{abstract}

\section{INTRODUCTION}

LeAf-CUTting ants of the genus Atta culture a fungus on fresh plant material collected from the surrounding forest. The ants exploit this fungus, which is believed to occur exclusively in attine nests, as their primary and probably sole food source (Belt, 1874; Müllek, 1874; WheELer, 1907; Weber, 1972). Atta workers characteristically defaecate on the plant material prior to incorporating it into their fungus gardens (HUBER, 1905; WEBER, 1972). In previous studies we have reported that the faecal material of the attine ants contains enzymes active in the degradation of protein, chitin, and starch (MARTIN and MarTin, 1970a, b, 1971; MarTin et al., 1973). Since it was also noted that the fungus cultured by Atta colombica tonsipes grows very poorly in a culture medium in which nitrogen is present predominantly in polypeptide form, we suggested that the faecal enzymes applied to the leaf fragments by the ants served an adaptive function by catalyzing the degradation of the substrate protein, thus facilitating fungal growth.

This study was undertaken with the objective of establishing the biochemical basis for the capacity of the attine ants to excrete large quantities of enzymes, a trait which differentiates them from other ants and most other insects. To this end we have purified the faecal proteinases of Atta texana and Atta colombica tonsipes, and have characterized them with regard to certain physical, chemical, and catalytic properties. These studies have provided insight into the origins of the faecal enzymes, hitherto assumed to be digestive enzymes produced in the midguts of the ants, and have also identified several characteristics of the enzymes which contribute to their extraintestinal function. In this study we have also tested the effect of the rectal proteolytic enzymes on the growth characteristics of the fungus in a culture medium in which soluble polypeptides constitute the nitrogen source, and have demonstrated a growth-enhancing effect. 
Ants

\section{MATERIALS AND METHODS}

Approximately $2 \mathrm{lb}$ of live workers of Atta texana (Buckley) were obtained in Grant Parish, Louisiana. Sticks were inserted repeatedly into the corridors of a large excavated nest, and the ants which attached themselves to the stick were scraped into a smoothsided plastic bucket, the inside of which had been sprayed with Fluororglide to prevent the ants from climbing out. Live workers of Atta colombica tonsipes Santschi were obtained from a captive colony at the University of Michigan.

\section{Obtention of rectal fluid}

For small scale studies rectal fluid was obtained by removing it from dissected rectums with a fine capillary needle attached to a syringe. A less tedious procedure, and the only feasible one when large quantities of material were needed, involved inducing the ants to defaecate in a crystallizing dish by immersion in ether. The ether and dead ants were poured off, leaving the amber droplets of faecal fluid coating the bottom of the container. After removing the remaining traces of ether in vacuo, the rectal fluid was washed off the bottom of the container with a minimum volume of $0.01 \mathrm{M}$ phosphate buffer $(\mathrm{pH} 7 \cdot 0)$, or distilled deionized water. When very large numbers of ants were subjected to this treatment, it was also necessary to wash the dead ants with buffer or water in order to remove adhering faecal fluid. Dissection of ants treated in this fashion revealed rectums which were nearly empty, but midguts which were still full and intact. SDS* gels of faecal fluid obtained by the two methods were identical in all salient details when stained for protein, or when sliced into $2 \mathrm{~mm}$ segments and assayed for proteolytically active bands. Employing either procedure the proteolytic activity of the rectal fluid obtained is from 50 to $70 \%$ higher if the ants are kept for $24 \mathrm{hr}$ without food or water between collection and sacrifice.

By either method, rectal fluid was obtained which exhibited proteolytic activity (per ant) equivalent to 55 to $130 \mathrm{ng}$ of trypsin (assayed as described below). Pooled rectal fluid could be kept frozen at $-20^{\circ} \mathrm{C}$ for 6 months without significant loss of activity.

\section{Purification of rectal proteases}

From approximately $2 \mathrm{lb}$ of $A$. texana, subjected to ether immersion and subsequent washing with $0.01 \mathrm{M}$ phosphate buffer $(\mathrm{pH} \mathrm{7.00)}$, a solution of rectal fluid exhibiting total proteolytic activity equivalent to $7.6 \mathrm{mg}$ of trypsin was obtained. Ammonium sulphate was added in small aliquots to this solution at $4^{\circ} \mathrm{C}$ until $20 \%$ saturation had been reached. After standing for $4 \mathrm{hr}$, the precipitate (which contained less than $1 \%$ of the total proteolytic activity) was removed by centrifugation $(15,000 \mathrm{~g}, 20 \mathrm{~min})$ and discarded. The supernatant was brought to $80 \%$ saturation by further addition of ammonium sulphate and allowed to stand for $4 \mathrm{hr}$ at $4^{\circ} \mathrm{C}$. After centrifugation $(15,000 \mathrm{~g}, 20 \mathrm{~min})$, the precipitate was

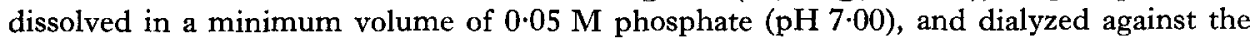
same buffer. The resulting solution contained $93 \%$ of the total proteolytic activity of the original extract.

The enzyme solution obtained above was passed through a column $(2.5 \times 37.5 \mathrm{~cm})$ of Sephadex G-75 equilibrated with $0.05 \mathrm{M}$ phosphate ( $\mathrm{pH} 7 \cdot 00$ ). The elution profile (Fig. 1, Results) revealed that the proteolytic activity of the rectal fluid could be attributed to three enzymes of differing molecular weight, hereafter designated proteinases I, II, and III, in order of decreasing molecular weight. Subsequent references to studies on purified proteinase I refer to experiments utilizing fractions 23 through 28.

* Abbreviations used: BSA, bovine serum albumin; CBZ, benzyloxycarbonyl; CHTG, chymotrypsinogen; CYTO C, cytochrome C; DEAE, diethylaminoethyl; DFP, diisopropylphosphofluoridate; EDTA, ethylenediamine tetraacetate; OVAL, ovalbumin; SBTI, soybean trypsin inhibitor; SDS, sodium dodecyl sulphate; TCA, trichloroacetic acid; TLCK, N-tosyl-L-lysyl chloromethyl ketone. 
Fractions 35 to 65 containing proteases II and III were pooled, dialyzed twice against $0.01 \mathrm{M}$ Tris $-\mathrm{HCl}(\mathrm{pH} 8.0)$ at $4^{\circ} \mathrm{C}$, then applied to a column $(1.5 \times 20.5 \mathrm{~cm})$ of DEAEcellulose, previously equilibrated and washed with the same buffer. After passage of an inactive protein fraction through the column, two active proteinases were eluted by a linear $\mathrm{NaCl}$ gradient (Fig. 2, Results), emerging at approximately $0.13 \mathrm{M}$ and $0.17 \mathrm{M} \mathrm{NaCl}$. Subsequent molecular weight determinations revealed that the first peak was proteinase III, the second one, proteinase II. Fractions 110 to 123 (proteinase III) and 145 to 160 (proteinase II) were pooled and dialyzed three times against distilled deionized water, and lyophilized. Subsequent references to studies on the purified proteinases II and III refer to these pooled fractions.

\section{Electrophoresis}

Disc electrophoresis in polyacrylamide was performed at $4^{\circ} \mathrm{C}$ according to Davis (1964) using $7.5 \%$ gels, pH 8.7 and $3 \mathrm{~mA} /$ gel tube. For basic proteins, the procedure of Reisfeld et al. (1962) was employed, using $10 \%$ gels, $\mathrm{pH} \mathrm{4.5}$, and $3 \mathrm{~mA} /$ gel tube. Prior to application, samples were diluted tenfold with $40 \%$ sucrose. Proteins were stained with $0.25 \%$ Coomassie brilliant blue in methanol-acetic acid-water $(5: 1: 5)$ and destained with methanol-acetic acid-water $(5: 1.5: 13 \cdot 5)$. Location of proteolytic activity was achieved by slicing chilled gels into $2 \mathrm{~mm}$ segments, placing the slices in test tubes containing $3 \mathrm{ml}$ of $0 \cdot 1 \mathrm{M}$ phosphate buffer ( $\mathrm{pH} \mathrm{7.00)}$ and $25 \mathrm{mg}$ of Azocoll (Calbiochem), and incubating with agitation for $6 \mathrm{hr}$ at $37^{\circ} \mathrm{C}$. After filtration, the adsorbance of the filtrate at $520 \mathrm{~nm}$ was determined.

\section{Molecular weight determinations}

Calibrated gel filtration on a Sephadex G-75 column $(2.5 \times 37.5 \mathrm{~cm})$ equilibrated with $0.05 \mathrm{M}$ phosphate (pH 7.00), standardized with BSA $(67,000)$, OVAL $(43,000)$, SBTI $(21,500)$ and CYTO C $(11,700)$ was carried out on purified samples of proteinases I, II, and III using the procedure of ANDREws (1964).

Molecular weight estimation by SDS-polyacrylamide electrophoresis was carried out on $10 \%$ acrylamide-0.1\% SDS gels according to WEBER and OsBORN (1969). Samples were prepared for application by adding small volumes of enzyme solution to $100 \mu \mathrm{l}$ of buffer ( $0.01 \mathrm{M}$ sodium phosphate, $\mathrm{pH} 7 \cdot 2,0.25 \% \mathrm{SDS}, 1.5 \% \beta$-mercaptoethanol, $10 \%(\mathrm{v} / \mathrm{v})$ glycerol, $0.002 \%$ bromophenol blue) and heating the mixture at $60^{\circ} \mathrm{C}$ for $15 \mathrm{~min}$. Calibration standards were BSA $(67,000)$, OVAL $(43,000)$, CHTG A $(25,000)$ and CYTO C $(11,700)$. Gels were stained with Coomassie brilliant blue.

\section{Proteinase assays}

Proteolytic activity was routinely assayed at $37^{\circ} \mathrm{C}, \mathrm{pH} 7 \cdot 00$, with Azocoll by a modification of the described procedure (Calbiochem, LaJolla, California, Document 3805). A volume of $0.1 \mathrm{M}$ cacodylate buffer, $\mathrm{pH} 7.00$, calculated to result in a final volume for the reaction mixture of $0.5 \mathrm{ml}$ after addition of the enzyme solution, was placed in a test tube $(10 \times 75 \mathrm{~mm})$ containing $25 \mathrm{mg}$ of Azocoll. The suspension was held at $37^{\circ} \mathrm{C}$ for $3 \mathrm{~min}$, after which an aliquot of enzyme solution was added, the mixture agitated gently, and then incubated at $37^{\circ} \mathrm{C}$ for $30 \mathrm{~min}$. The reaction was terminated by the addition of $2.5 \mathrm{ml}$ of $10^{-3} \mathrm{M} \mathrm{HCl}$. The tube was vortexed briefly, then centrifuged. Adsorbance of the supernate was read at $520 \mathrm{~nm}$ on a Coleman Jr. Spectrophotometer. Control values were obtained by substituting samples which had been inactivated by boiling enzymatically active samples. This assay was standardized using aliquots of a bovine trypsin solution of known concentration. Activity was proportional to trypsin concentrations up to $400 \mathrm{ng} /$ incubation mixture. Since a linear relationship between activity and the volume of the rectal fluid added to the assay mixture is also observed in the same activity range, the proteo- 
lytic activity of the rectal enzymes is conveniently converted to trypsin equivalents using the standardization plot.

Enzymatic hydrolysis of casein (Hammerstein) was conducted at $\mathrm{pH} 7 \cdot 6,30^{\circ} \mathrm{C}$, by the method of KuniTz (1947) as described by RICK (1963). Activity toward acid-denatured hemoglobin was determined according to ANSON (1938) as modified by KATZENELLENBOGEN and Kafatos (1971). Activity toward gelatin was detected by noting the effect of crude rectal fluid on photographic film (Fratello, 1968). Activity toward both native and denatured $\mathrm{BSA}\left(1 \%\right.$ solutions) was determined at $\mathrm{pH} 7.00$ and $25^{\circ} \mathrm{C}$ by withdrawing aliquots from the assay mixture, effecting precipitation with cold $10 \% \mathrm{TCA}$, filtering through a Millipore filter and measuring the adsorbance of the filtrate at $280 \mathrm{~nm}$. Lytic activity of crude rectal fluid and proteinase III was tested against cells of Staphylococcus aureus and Micrococcus lysodeickticus according to the procedure of ENSIGN and WOLFE (1965).

\section{Effect of inhibitors on activity}

Rectal fluid or samples of the purified enzymes were incubated with the inhibitor for $160 \mathrm{~min}, 25^{\circ} \mathrm{C}$, in a buffer $(0.01 \mathrm{M}$ cacodylate, $\mathrm{pH} 7.00$ for DFP, EDTA, phenanthroline, $\mathrm{HgCl}_{2} ; 0.01 \mathrm{M}$ phosphate, $\mathrm{pH} 7.00$ for SBTI, TLCK; $0.005 \mathrm{M}$ phosphate, $\mathrm{pH} 6.00$ for iodoacetate and $p$-chloromercuribenzoate). Proteolytic activity toward Azocoll was assayed before and after incubation.

\section{Dependence of activity on $p H$}

$\mathrm{pH}$-activity profiles were obtained by assaying activity against Azocoll at various $\mathrm{pH}$ 's: $\mathrm{pH} 4 \cdot 5$ to $5 \cdot 5,0 \cdot 1 \mathrm{M}$ acetate; $\mathrm{pH} 5 \cdot 5-7 \cdot 5,0 \cdot 1 \mathrm{M}$ phosphate for proteinase $\mathrm{I}, 0 \cdot 1 \mathrm{M}$ cacodylate for II and III; $\mathrm{pH} 7 \cdot 5$ to $9 \cdot 0,0.1 \mathrm{M}$ Tris- $\mathrm{HCl} ; \mathrm{pH} 9 \cdot 0$ to $10 \cdot 0,0 \cdot 1 \mathrm{MI} \mathrm{Na} \mathrm{CO}_{3}-\mathrm{NaHCO}_{3}$. Proteinase I was preincubated for $1 \mathrm{hr}$ at $4^{\circ} \mathrm{C}$ with $0.01 \mathrm{M}$ EDTA to ensure deactivation of proteinase II or III which might have been present as contaminants in the preparation.

\section{Dependence of stability on $\mathrm{pH}$}

The stability of rectal fluid proteolytic activity at various $\mathrm{pH}$ 's was determined by incubating aliquots of crude rectal fluid for $2.25 \mathrm{hr}$ at $25^{\circ} \mathrm{C}$ at various $\mathrm{pH}$ 's: $\mathrm{pH} 1.25$ and $1.65,0.05 \mathrm{M} \mathrm{KCl}-\mathrm{HCl} ; \mathrm{pH} 3.0$ to $4.0,0.05 \mathrm{M}$ citrate-phosphate; $\mathrm{pH} 4.5$ to $5.5,0.05 \mathrm{M}$ acetate; $\mathrm{pH} 6.0$ to $7.5,0.05 \mathrm{M}$ phosphate; $\mathrm{pH} 8.0$ to $9.0,0.05 \mathrm{M}$ Tris- $\mathrm{HCl} ; \mathrm{pH} 10,0.1 \mathrm{M}$ $\mathrm{Na}_{2} \mathrm{CO}_{3}-\mathrm{NaHCO}_{3}$. Proteolytic activity was assayed agzinst Azocoll before and after incubation, and results are reported as percentage activity remaining after incubation. Samples of proteinases II and III and of rectal fluid were also incubated for longer periods $(20$ and $40 \mathrm{hr}$ ) at $\mathrm{pH}$ 's 5.7 and 6.0 .

\section{Determination of crop, midgut and rectal fluid $p H$}

The pH's of crop, midgut, and rectal fluids, obtained by dissection of 10 to 15 live workers of $A$. texana, were determined using a microelectrode (Instrumentation Laboratories) connected to a Corning Model $12 \mathrm{pH}$ Meter.

\section{Amino acid esterase activity}

Amino acid esterase specificity was determined by measuring initial rates of hydrolysis of various substrates using a Radiometer TTl pH Stat. Proteinase I was preincubated for $1 \mathrm{hr}$ with $0.01 \mathrm{M}$ EDTA to ensure deactivation of proteinases II or III which might have been present as contaminants in the preparation. Assay mixtures (total volume, $4 \mathrm{ml}$ ) containing $10^{-3} \mathrm{M}$ substrate, $2.5 \times 10^{-4} \mathrm{M}$ phosphate, $0 \cdot 1 \mathrm{M} \mathrm{KCl}$, and $2.5 \%$ acetonitrile were adjusted to $\mathrm{pH} 7 \cdot 00$. The reaction was started by adding an aliquot of the enzymatically active sample, and the volume of base $\left(5 \times 10^{-3} \mathrm{M} \mathrm{NaOH}\right)$ required to maintain the $\mathrm{pH}$ at 7.00 was recorded manually as a function of time. Linear addition of base was observed up to $10 \%$ reaction. 
The following substrates were obtained from Cyclo Chemical: N-benzoylglycine methyl ester, N-benzoyl-L-histidine methyl ester, N-benzoyl-L-methionine methyl ester, N-CBZL-alanine methyl ester, $\mathrm{N}-\alpha$-acetyl-L-lysine methyl ester. The following substrates were kindly provided by Professor Jules A. SHAFER, University of Michigan: N-benzoyl-Larginine ethyl ester and N-acetyl-L-tyrosine ethyl ester. The following N-CBZ-L-amino acids were obtained from Nutritional Biochemicals: N-CBZ-L-valine, N-CBZ-L-leucine, N-CBZ-L-phenylalanine, N-CBZ-L-proline, N-CBZ-L-hydroxyproline, N-CBZ-L-serine, $\mathrm{N}-\mathrm{CBZ}$-L-threonine, N-CBZ-L-tryptophan, and N-CBZ-L-asparagine. To methanolic solutions of each of the above N-CBZ-amino acids was added an ethereal solution of diazomethane (generated from Diazald) until nitrogen evolution ceased and the yellow colour of diazomethane persisted. After removal of ether at reduced pressure, the product methyl ester was recrystallized from water. Purity was established by TLC on silica gel plates developed in chloroform: methanol $(9: 1)$ or chloroform : methanol : acetic acid $(8 \cdot 5: 1: 0 \cdot 5)$.

Using the same general procedure, while maintaining a different constant $\mathrm{pH}$, a $\mathrm{pH}$ profile for the activity of proteinase I toward N-benzoyl-L-methionine methyl ester was obtained.

\section{Amidase activity}

Amidase activity was examined in proteinases II and III by incubating N-CBZ-Ltyrosyl leucine amide $\left(10^{-3} \mathrm{M}\right)$ in $0.5 \mathrm{ml}$ of cacodylate buffer $(0.1 \mathrm{M}, \mathrm{pH} 7.00)$ containing $10 \%$ dimethylformamide. The hydrolysis was followed by conducting ninhydrin determinations (MOORE and STEIN, 1958) on $50 \mu \mathrm{l}$ aliquots removed from the incubation mixture. When the reaction was complete, the reaction mixture was lyophilized, dissolved in ethanol and applied to a silica gel TLC plate. The plate was developed with $n$-butanol : acetone : acetic acid : $5 \%$ ammonia $(4 \cdot 5: 1 \cdot 5: 1: 2)$. Products of hydrolysis were identified by comparison with authentic samples of N-CBZ-tyrosine (visualized by a Fast B Blue spray) and leucine amide $\mathrm{HCl}$ (visualized by a ninhydrin spray).

\section{Digestion of insulin A-chain (oxidized)}

Three $\mathrm{mg}$ of oxidized insulin A chain (Schwarz/Mann), purified by Sephadex G-25 filtration, was dissolved in $1.25 \mathrm{ml}$ of $0.01 \mathrm{M}$ cacodylate buffer $\left(\mathrm{pH} 7.00\right.$ ) containing $10^{-3} \mathrm{M}$ $\mathrm{CaCl}_{2}$ and about $50 \mu \mathrm{g}$ trypsin equivalents of proteinases I, II, or III. The reaction mixtures were incubated at $37^{\circ} \mathrm{C}$, and the liberated free amino groups were followed using the photometric ninhydrin procedure of MOORE and STEIN (1958). For proteinase I, digestion was allowed to continue until no further increase in free amino groups was observed. Since preliminary experiments had indicated that for both proteinases II and III, two peptide bonds were hydrolyzed at a fast rate followed by a much slower hydrolysis of at least two more peptide linkages, the digestion was terminated (by the addition of a drop of glacial acetic acid) when the ninhydrin determination indicated that two peptide bonds had been hydrolyzed. Reaction mixtures were applied as a narrow band across the middle of $20 \times$ $20 \mathrm{~cm}$ thin layer cellulose sheets which had been sprayed and equilibrated with pyridine : acetic acid : water $(2: 20: 178, \mathrm{pH} 3 \cdot 5)$. Electrophoresis was conducted at $200 \mathrm{~V}$ for $1.5 \mathrm{hr}$ in the above buffer. After drying overnight, peptide bands were located by cutting horizontal strips from each border and dipping them in $1 \%$ ninhydrin $-0.1 \%$ cadmium acetate in acetone (HEILMAN et al., 1957). For proteinases II and III, the single peptide which migrated to the cathode was eluted with $50 \%$ acetic acid, hydrolyzed in $6 \mathrm{~N} \mathrm{HCl}$, and the hydrolyzate subjected to amino acid analysis.

\section{Fungal growth studies}

Growth was determined in a shaken liquid culture $\left(180 \mathrm{rev} / \mathrm{min}, 25^{\circ} \mathrm{C}\right)$ in $50 \mathrm{ml}$ of 
Sabouraud's broth (Nutritional Biochemicals Corp.), sterilized by autoclaving at $120^{\circ} \mathrm{C}$ for $20 \mathrm{~min}$. Flasks were inoculated with $1 \mathrm{ml}$ of a seed culture of the fungus grown by $A$. c. tonsipes, homogenized for $10 \mathrm{sec}$ in a Waring blender. After inoculation, aliquots of crude rectal fluid from $A$. $c$. tonsipes, purified rectal proteinases from $A$. c. tonsipes, or Sigma Type VI fungal protease were added through Millex filter units or Swinney adapters. After 12 days of growth, the cultures were filtered, and the recovered mycelial mats dried for $6 \mathrm{hr}$ at $60^{\circ} \mathrm{C}$ then weighed.

\section{Purification of rectal proteinases}

\section{RESULTS}

Rectal fluid derived from approximately two pounds of Atta texana exhibited total proteolytic activity equivalent to $7.6 \mathrm{mg}$ of trypsin. Chromatography on Sephadex G-75 of an active fraction obtained by ammonium sulfate precipitation revealed that the activity of the rectal fluid is derived from three separate enzymes (Fig. 1). The first enzyme to be eluted (proteinase I) accounts for about $20 \%$ of

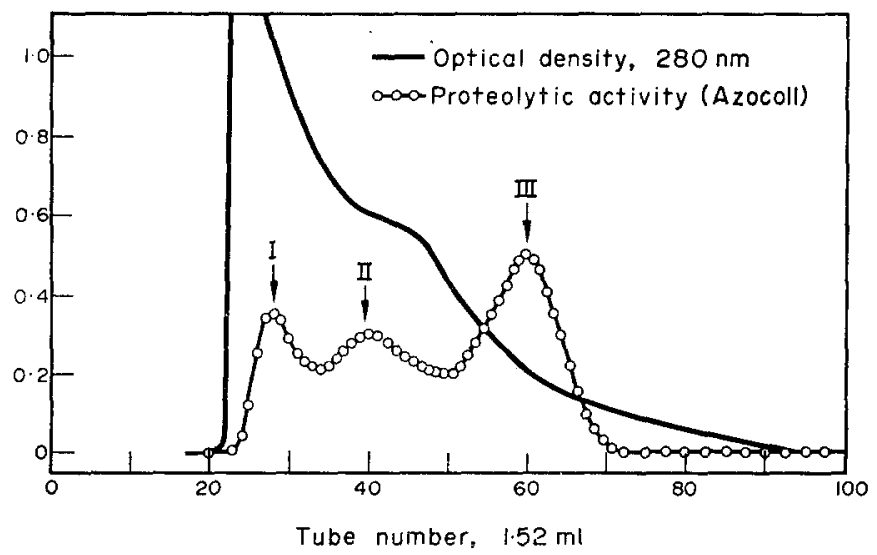

FIG. 1. Gel permeation of faecal proteinases precipitated by $\left(\mathrm{NH}_{4}\right)_{2} \mathrm{SO}_{4}$ on Sephadex G-75 equilibrated with $0.05 \mathrm{M}$ phosphate, $\mathrm{pH} 7.00$. $\mathrm{O}-\mathrm{O}$, activity toward Azocoll.

the total activity, the second (proteinase II) for 30 to $35 \%$ of the total activity, and the third (proteinase III) for 45 to $50 \%$.

Further purification of proteinases II and III was achieved by pooling the fractions from the Sephadex G-75 column containing these two enzymes, and subjecting the reconstituted mixture to chromatography over a DEAE-cellulose column, eluting with a linear $\mathrm{NaCl}$ gradient (Fig. 2). Analysis for proteolytic activity of gel slices following electrophoresis revealed only one active band in the preparations of each of the proteinases II and III. Neither of the preparations was concentrated enough to detect absorption at $280 \mathrm{~nm}$, although the presence of protein could be demonstrated using the Folin-Ciocalteau reagent. 


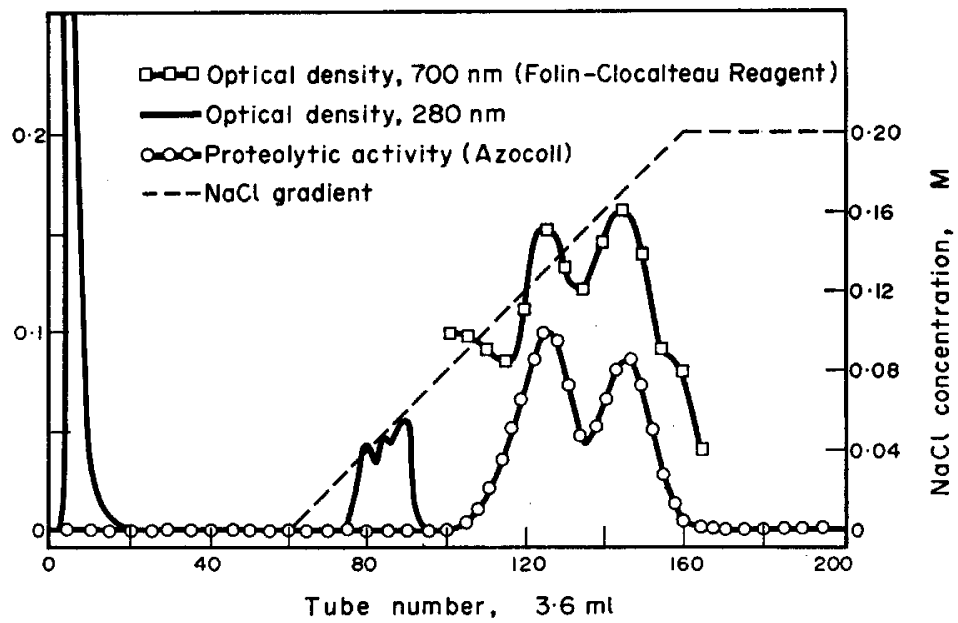

Fig. 2. Chromatography of combined fractions 35 to 65 derived from the Sephadex G-75 column (Fig. 1) on DEAE-cellulose, eluting with $0.01 \mathrm{M}$ Tris- $\mathrm{HCl}, \mathrm{pH} 8 \cdot 0$. The sample was equilibrated with the buffer by dialysis prior to application to the column. After 60 fractions had been collected, the ionic strength of the eluting buffer was increased by means of a linear $\mathrm{NaCl}$ gradient. The first enzyme to elute corresponds to protease III from the Sephadex G-75 column, the second to protease II. $\longrightarrow$, O.D. at $280 \mathrm{~nm} ; \square-\square, O . D$. at $700 \mathrm{~nm}$, Folin-Ciocalteau protein determination (LowRY et al., 1951); $\bigcirc-O$, proteolytic activity toward Azocoll; $---\mathrm{NaCl}$ gradient.

Fractionation of the rectal fluid derived from Atta colombica tonsipes by the same procedure revealed the presence of the same three enzymes. Since the amount of material available from $A$. texana was much greater than from $A$. c. tonsipes, the characterization of the rectal enzymes was directed primarily at those derived from the former species, and unless otherwise stated, the results described and discussed below all refer to the enzymes of texana.

\section{Physical properties of the proteinases}

Molecular weights. SDS-polyacrylamide gel electrophoresis (Fig. 3a) indicated mol. wt of 41,700 and 14,900 for proteinases II and III, respectively. A calibrated gel filtration on Sephadex G-75 (Fig. 3b) indicated mol. wt of proteinases I, II, and III of $70,000,40,800$, and 15,500 , respectively. The value obtained for proteinase I must be regarded only as a rough estimate, since mol. wt in this high range are only approximately determined by this procedure (ANDREws, 1964).

Electrophoretic behavior. Both proteinases II and III migrated as anodic bands in polyacrylamide gels at $\mathrm{pH} 8.7$ with Rm's of 0.73 and 0.61 , respectively. Electrophoretic analysis of crude rectal fluid, from both $A$. texana and $A$. $c$. tonsipes, revealed two proteolytically active bands corresponding to proteinases II and III. Proteinase I could not be located electrophoretically in crude rectal fluid. 


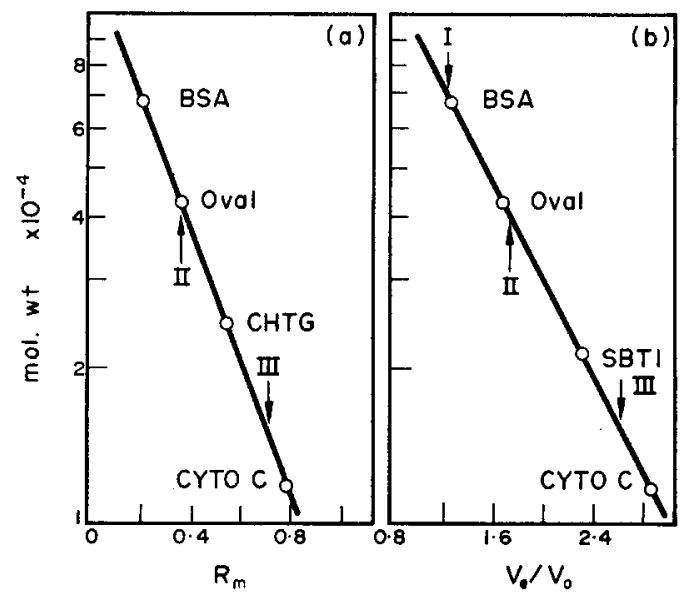

FIG. 3. The mol. wt of proteinases I, II and III as determined by (a) calibrated SDS-polyacrylamide gel electrophoresis and (b) calibrated Sephadex G-75 gel filtration.

Whether this is because proteinase I is denatured, migrates with proteinases II or III, or is a basic protein could not be ascertained, since insufficient purified proteinase I was available for the requisite experiments.

\section{Enzymological studies}

Scope of proteolytic activity. Faecal fluid readily degrades typical protein substrates such as casein, gelatin, acid-denatured haemoglobin, and BSA. Rectal fluid hydrolyzes native BSA 60 to $70 \%$ as rapidly as it hydrolyzes denatured BSA.

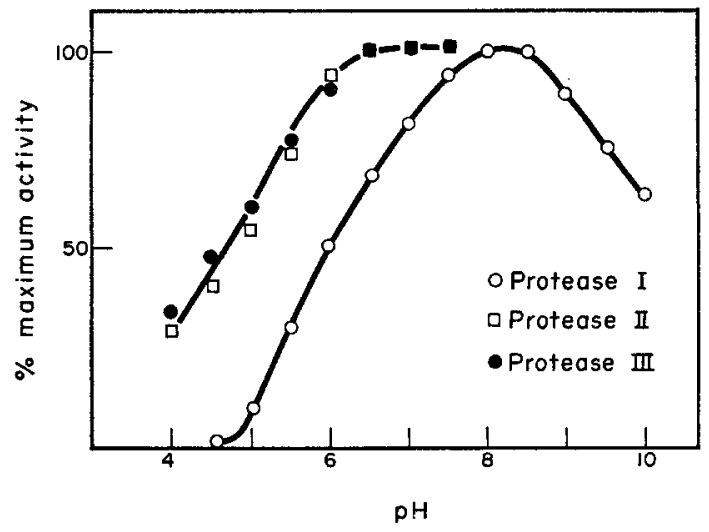

FIG. 4. Proteolytic activity toward Azocoll of proteinases I, II, and III at various pH's. Proteinases II and III exhibit such similar pH profiles that a single curve has been drawn through the points corresponding to these two enzymes. 
The hydrolysis of Azocoll, an insoluble derivatized protein from hide, serves as a convenient and sensitive assay for the faecal enzymes.

Effect of $p H$ on proteolytic activity. The rectal fluid exhibits its maximum activity toward Azocoll between $\mathrm{pH}$ 's of 6.5 and 9.0 . This broad activity maximum results from the summation of the $\mathrm{pH}$ profiles of the component enzymes (Fig. 4). Proteinase I is optimally active under weakly alkaline conditions, whereas proteinases II and III, which have similar $\mathrm{pH}$ profiles, exhibit maximum activity under weakly acidic or neutral conditions.

Effect of $p H$ on the stabilities of the proteinases. The rectal proteinases are remarkably stable in the $\mathrm{pH}$ range between $5 \cdot 0$ and 7.5 (Fig. 5). Even after $40 \mathrm{hr}$ at $\mathrm{pH} 5.7$ at $25^{\circ} \mathrm{C}$, conditions resembling those encountered in the ant's gut, where

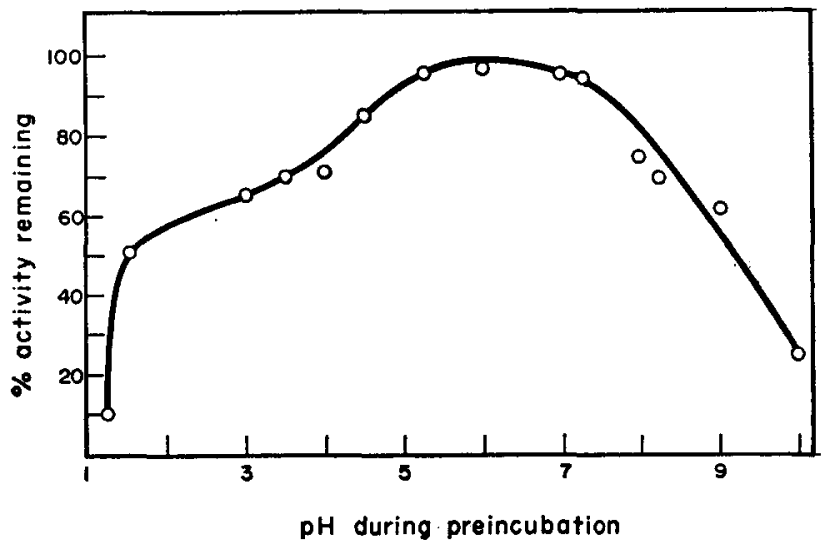

FIG. 5. Stability of rectal fluid proteolytic activity at various pH's. Aliquots of crude rectal fluid were incubated for $2.25 \mathrm{hr}$ at $25^{\circ} \mathrm{C}$ in appropriate buffers (See Materials and Methods). Proteolytic activity was assayed toward Azocoll before and after incubation.

the $\mathrm{pH}$ 's of the crop, midgut and rectum are approximately $7 \cdot 2,6 \cdot 5$, and $5 \cdot 8$, respectively, rectal fluid, diluted 3- or 4-fold with water, showed a loss of only $15 \%$ of its original activity. Fractions containing purified proteinases II and III retained at least $90 \%$ of their original activity when incubated at $\mathrm{pH} 6.0$ for $20 \mathrm{hr}$. These incubation times are considerably longer than the residence time of material in the ant's gut (unpublished studies of J. S. MarTin and M. M. MarTin).

Effect of inhibitors on activity. Preincubation of the crude rectal fluid with DFP resulted in a $20 \%$ loss of proteolytic activity (Table 1). Preincubation with EDTA caused a loss of $80 \%$ of activity. When both inhibitors were present in the preincubation mixture, $100 \%$ loss of proteolytic activity was observed.

When proteinase I was similarly investigated, total inhibition of activity was caused by DFP, whereas EDTA had no inhibitory effect. By contrast, proteinases II and III were unaffected by DFP but were completely inhibited by EDTA. Also, 
TABLE 1-EFfeCt of INHIBITORS ON PROTEOLYTIC ACTIVITY OF CRUDE RECTAL FLUID AND PURIFIED PROTEINASES I, II AND III

\begin{tabular}{|c|c|c|c|c|}
\hline \multirow[b]{2}{*}{ Inhibitor (Conc., M) } & \multicolumn{4}{|c|}{ Residual activity $(q)$} \\
\hline & Rectal fluid & $I$ & II & III \\
\hline None & 100 & 100 & 100 & 100 \\
\hline $\operatorname{DFP}\left(10^{-3}\right)$ & 80 & 0 & 100 & 100 \\
\hline EDTA $\left(10^{-2}\right)$ & 20 & 100 & 0 & 0 \\
\hline 1,10 -Phenanthroline $\left(10^{-3}\right)$ & -- & 100 & $<5$ & $<5$ \\
\hline $\begin{array}{l}\text { 1, lo-Phenanthroline }\left(10^{-3}\right) \\
\text { followed by } \operatorname{Zn}\left(\mathrm{NO}_{3}\right)_{2}\left(5 \times 10^{-3}\right)\end{array}$ & - & -- & 74 & 80 \\
\hline $\mathrm{HgCl}_{2}\left(10^{-5}\right)$ & -- & -- & 47 & 52 \\
\hline $\mathrm{HgCl}_{2}\left(5 \times 10^{-5}\right)$ & -- & -- & 13 & 17 \\
\hline $\mathrm{HgCl}_{2}\left(10^{-4}\right)$ & -- & -- & 0 & 0 \\
\hline Iodoacetate $\left(10^{-3}\right)$ & -- & $>90$ & $>90$ & $>90$ \\
\hline $\mathrm{p}$-Chloromercuribenzoate $\left(10^{-3}\right)$ & -- & $>90$ & $>90$. & $>90$ \\
\hline $\operatorname{SBTI}\left(10^{-5}\right)$ & 100 & -- & - & - \\
\hline $\operatorname{TLCK}\left(5 \times 10^{-3}\right)$ & 100 & - & - & -- \\
\hline
\end{tabular}

proteinases II and III, but not I, were over $95 \%$ inhibited by 1,10-phenanthroline. The addition of $\mathrm{Zn}\left(\mathrm{NO}_{3}\right)_{2}$ following 1,10-phenanthroline treatment regenerated between 74 and $80 \%$ of the proteolytic activity in proteinases II and III.

Both proteinases II and III were inhibited by high concentrations of mercuric ions. Complete inhibition was effected by preincubation with $10^{-4} \mathrm{M} \mathrm{HgCl}_{2}$, whereas only about $50 \%$ inhibition resulted with $10^{-5} \mathrm{M} \mathrm{HgCl}_{2}$. The susceptibility of these proteinases to mercuric ion inhibition is greater than that reported for trypsin (GREEN and NEURATH, 1953) but considerably less than observed for the sulphydryl proteinase bromelain, where a $1: 1$ reaction has been demonstrated (Murachi and Neurath, 1960).

Iodoacetate and $p$-chloromercuribenzoate had only small inhibitory effects $(<10 \%)$ on all three proteinases. SBTI and TLCK, both specific inhibitors of trypsin, did not effect the activity of crude rectal fluid.

Specificity. Crude rectal fluid was observed to catalyze the hydrolysis of esters of $\mathrm{N}$-substituted amino acids. Studies on the purified enzyme preparations revealed that this activity is due exclusively to proteinase I, the DFP-sensitive enzyme. A comparison of the rates of hydrolysis of a series of $\mathrm{N}$-substituted amino acid esters, catalyzed by proteinase I, reveals that this enzyme does not exhibit high substrate specificity, but rather possesses broad, general catalytic properties ('Table 2). Of particular relevance is the lack of any preference for derivatives of lysine, arginine, phenylalanine, tyrosine and tryptophan, the preferred substrates of typical trypsin and chymotrypsin-like proteinases. Prolonged digestion of the oxidized insulin A chain by proteinase I, followed by electrophoresis, revealed eight major bands and many minor bands, further emphasizing the broad specificity of this enzyme. 
Table 2-Relative rates of hydrolysis of N-substituted amino acid esters in the PRESENCE OF PROTEINASE I

\begin{tabular}{lr}
\hline \multicolumn{1}{c}{ Substrates } & Relative Rate \\
\hline N-Benzoylglycine methyl ester & 3.5 \\
N-CBZ-L-alanine methyl ester & 16.8 \\
N-CBZ-L-valine methyl ester & 10.6 \\
N-CBZ-L-leucine methyl ester & 29.6 \\
N-CBZ-L-serine nethyl ester & 43.1 \\
N-CBZ-L-threonine methyl ester & 3.4 \\
N-CBZ-L-esparagine methyl ester & 7.8 \\
N-Acetyl-L-lysine methyl ester & 9.7 \\
N-Banzoyl-L-arginine ethyl ester & 39.8 \\
N-Benzoyl-L-histidine methyl ester & 15.8 \\
N-Benzoyl-L-methionine methyl ester & 100.0 \\
N-CBZ-L-phenylalanine methyl ester & 58.2 \\
N-Acetyl-L-tyrosine ethyl ester & 68.5 \\
N-CBZ-L-tryptophan methyl ester & 30.9 \\
N-CBZ-L-proline methyl ester & 11.0 \\
N-CBZ-L-hydroxyproline nethyl ester & 2.1 \\
\hline
\end{tabular}

The dependence of the rate of hydrolysis of N-benzoyl L-methionine methyl ester exhibits a maximum between 8 and 9 , and resembles the $\mathrm{pH}$ profile for the activity of proteinase I toward Azocoll.

The enzymatic hydrolysis of the oxidized insulin A chain by proteinases II and III gave identical initial cleavage products. Both enzymes caused the rapid hydrolysis of two peptide bonds followed by a much slower cleavage of at least two more bonds. If the reaction is stopped following the hydrolysis of the two labile bonds, and the reaction mixture subjected to thin-layer electrophoresis on cellulose at $\mathrm{pH} 3 \cdot 5$, two major peptide bands and several minor bands migrate to the anode while only one peptide migrates to the cathode. The single peptide which migrates toward the cathode was isolated and found to contain leucine, tyrosine and glutamic acid or glutamine. From a consideration of the amino acid sequence in the A-chain of insulin, this finding strongly suggests that the labile peptide bonds are serine ${ }_{(12)}$-leucine $_{(13)}$ and glutamine ${ }_{(15)}$-leucine $_{(16)}$ and suggestsa specificity for peptide bonds in which the amino group is contributed by a leucine residue.

The specificity of proteinases II and III was further probed using the synthetic substrate N-CBZ-L-tyrosyl-L-leucine amide. Proteinase II hydrolyzed this substrate at an initial rate approximately one eighth the rate observed for the hydrolysis of the insulin A-chain. Proteinase III accomplished the hydrolysis of this substrate at a much slower rate than proteinase II, and indeed it is even possible that the activity observed in the proteinase III preparation was due to contaminating traces of proteinase II. No exopeptidase activity for either proteinase II or III was detected using N-benzoyl-L-phenylalanine or L-leucine amide as substrates. Nor did proteinase III effect the lysis of Staphylococcus aureus or Micrococcus lysodeickticus cells. 


\section{Fungal growth studies}

The addition of crude rectal fluid derived from the ant Atta columbica tonsipes to a sterile shaken liquid culture of its natural fungus in Sabouraud's dextrose broth significantly increases the extent of fungal growth over a 12-day period (Table 3). The quantity of rectal fluid added to $50 \mathrm{ml}$ of culture medium was roughly comparable to the amount which can be obtained from 50 to 100 ants. Similar growth enhancement resulted from the addition of a solution of the three rectal proteinases prepared by combining suitable fractions from the Sephadex G-75 gel filtration step in the purification procedure, and from the addition of a non-specific proteinase derived from Streptomyces griseus (Sigma Type VI Fungal Protease).

TABLE 3-THE EFFECT OF RECTAL FLUID, PURIFIED RECTAL PROTEINASES AND A NON-SPECIFIC PROTEINASE FROM Streptomyces griseus ON THE GROWTH OF THE FUNGUS CULTURED BY Atta colombica tonsipes IN SHAKEN LIQUID CULTURE*

\begin{tabular}{|c|c|c|c|}
\hline $\begin{array}{l}\text { Material added } \\
\text { to culture } \\
\text { medium }\end{array}$ & $\begin{array}{l}\text { Trypsin equivalents } \\
\text { added to culture } \\
\text { medium }(\mathrm{Hg} / \mathrm{ml})\end{array}$ & $\begin{array}{l}\text { Dry weight } \\
\text { mycelia (mg) }\end{array}$ & S.E.M. (N) \\
\hline \multicolumn{4}{|l|}{ Run I: } \\
\hline None & 0.00 & 24.7 & $8.9(13)$ \\
\hline $\begin{array}{l}\text { Crude rectal } \\
\text { fluid }\end{array}$ & 0.10 & 300.4 & $19.1(5)$ \\
\hline $\begin{array}{l}\text { Combined } \\
\text { chromatographic } \\
\text { fractions } \\
\text { containing } \\
\text { proteinases I, } \\
\text { II, and III }\end{array}$ & 0.09 & 313.8 & $20.6(4)$ \\
\hline \multicolumn{4}{|l|}{ Run 2: } \\
\hline None & 0.00 & 7.1 & $4.9(10)$ \\
\hline $\begin{array}{l}\text { Crude rectal } \\
\text { fluid }\end{array}$ & 0.14 & 198.5 & $34.1(6)$ \\
\hline $\begin{array}{l}\text { Sigma type VI } \\
\text { fungal protease }\end{array}$ & 0.16 & 253.2 & 43.2 (11) \\
\hline
\end{tabular}

\section{DISCUSSION}

\section{General characteristics of the faecal proteinases}

The proteolytic activity of the faecal fluid of Atta texana and A. colombica tonsipes is attributable to three enzymes which are conveniently separated by gel filtration on Sephadex G-75.

These three enzymes, either separately or together, exhibit remarkable stability in the $\mathrm{pH}$ range from $5 \cdot 0$ to $7 \cdot 5$, a range which includes the $\mathrm{pH}$ normally encountered in the ant's gut, where pH's of $7 \cdot 2,6.5$ and 5.8 were determined in the crop, midgut, and rectum, respectively. This high stability is obviously relevant to the persistence of the enzymes in the rectal fluid of the ant. Indeed it seems clear that resistance to mutual or autodigestion is a requisite property of any set of enzymes destined to perform an adaptive catalytic function after being excreted by the organism, and it is gratifying to see such stability reflected in vitro. 
The broad $\mathrm{pH}$ optimum between 7 and 9 for the activity of the rectal fluid, and the relatively high activity at $\mathrm{pH}$ 's down to $5 \cdot 5$, would also seem to be of adaptive significance, since it would permit the rectal fluid to perform its extraintestinal catalytic function on a variety of natural substrates relatively independent of their intrinsic physiological pH's.

The observed broad catalytic activity of the rectal fluid and its component proteinases is also in accord with the proposed role of these enzymes, and would appear to reflect adaptive properties of the enzymes. These enzymes must degrade proteins of diverse origin and structure for subsequent metabolic utilization by the fungus. Clearly then, enzymes with broad, general activity will be better suited to perform this function than enzymes with narrow specificities.

Finally, we have demonstrated that the fungus of $A$. c. tonsipes will grow considerably faster in Sabouraud's dextrose broth, a culture medium in which the nitrogen source consists of soluble polypeptides derived from the partial enzymatic hydrolysis of natural proteins, if small amounts of the ants' rectal fluid are added. That this effect is due to the proteolytic activity of the rectal fluid is made manifest by noting that a comparable growth-enhancing effect results from the addition of a mixture of the three purified rectal proteinases, or by the addition of a general non-specific proteinase derived from the bacterium, Streptomyces griseus.

\section{Enzymological characterization of the fecal proteinases}

Proteolytic enzymes are commonly divided into four classes (NEURATH et al., 1967; MAHLER and CoRDES, 1966): acid proteinases, sulphydryl proteinases, serine proteinases, and metallopeptidases.

Proteinase $I$ is clearly a serine proteinase. It is inhibited by DFP, but not by iodoacetate, $p$-chloromercuribenzoate, or EDTA. Furthermore the enzyme has an alkaline $\mathrm{pH}$ optimum for both protein and amino acid ester substrates in common with other members of this group. Proteinase I, with a mol. wt of approximately 70,000 , appears to be somewhat larger than the typical members of this class, which generally have mol. wt which fall in the 20,000 to 35,000 range. However, higher mol. wt have been reported for a number of serine proteinases, including one isolated from the gut of the adult beetle, Tenebrio (Zwilling, 1968), and several isolated from microbial sources (MARTIN et al., 1962; MoRIHARA and TsuzUKI, 1969).

Certain other properties of proteinases I clearly set it apart from other animal proteinases of this class, and in particular from the enzymes derived from invertebrates. All of the serine proteinases previously reported from insects have specificities similar to mammalian trypsin and chymotrypsin, despite a diversity of physical properties (BRookes, 1963; APPLEBAUM et al., 1964; LECADET and Dedonder, 1966; Freeman, 1967; Kafatos et al., 1967a, b; Zwilling, 1968; Gooding and Huang, 1969; Sonnenborn et al., 1969, Bonger; and Nogge, 1970; Hruska and Law, 1970; Cheung and Gooding, 1971; Hagenmaier, 1971; Katzenellenbogen and Kafatos, 1971; Yang and Davies, 1971a, b; Feldsted, 1973). Proteinase I, however, does not exhibit the characteristic specificity of trypsin or chymotrypsin. Nor is it inhibited by SBTI or TLCK, two specific 
trypsin inhibitors. On the other hand, proteinase I does resemble typical serine proteases of microbial origin. Microbial enzymes of this class characteristically exhibit high catalytic activity toward protein substrates, and broad catalytic activity toward N-substituted amino acid esters, without showing high specificities for the peptide bonds preferred by typical animal trypsins or chymotrypsins (SANGER et al., 1955; Martin et al., 1962; Morihara and Tsuzuki, 1969). These are precisely the catalytic properties observed in proteinase I.

Proteinases II and III are metalloendopeptidases. Both enzymes are inhibited by the metal chelators EDTA and 1,10-phenanthroline, but are insensitive to DFP and the thiol reagents, iodoacetate and $p$-chloromercuribenzoate. The metal ion required for activity by proteinases II and III appears to be zinc, since the addition of zinc nitrate to 1,10 -phenanthroline-inhibited samples restores activity. In common with other endopeptidases of this class, both proteinases II and III exhibit $\mathrm{pH}$ optima near neutrality and do not exhibit any esterolytic activity toward N-substituted amino acid esters. Enzymes of this type generally have mol. wt in the range 35,000 to 50,000. Proteinase II, with a mol. wt of about 41,000, appears to be typical. Proteinase III has a somewhat lower mol. wt $(15,000)$, but other metalloendopeptidases of similar low mol. wt have been reported (JACKSON and WoLFE, 1968).

In general, proteinases of this group preferentially cleave peptide bonds in which the amino acid residue contributing the amino group bears a hydrophobic side chain (Matsubara et al., 1966; Feder and Lewis, 1967; Millet and Archer, 1969). Both proteinases II and III exhibit similar specificity and effect preferential cleavage of the insulin A-chain at the serine ${ }_{(12)}$-leucine $_{(13)}$ and glutamine ${ }_{(15)}{ }^{-}$ leucine $_{(16)}$ bonds. Proteinase II also hydrolyzes the peptide bond of the synthetic substrate, N-CBZ-L-tyrosyl-L-leucine amide, a substrate which is similarly attacked by a number of other neutral metalloendopeptidases. Proteinase III, on the other hand, hydrolyzes this substrate slowly if at all. In this connection it is noteworthy that the metalloendopeptidase from Myxobacter AL-1, which also has a low mol. wt $(14,000)$ in common with proteinase III, also fails to hydrolyze similar synthetic substrates although it readily hydrolyzed the insulin B-chain (JACKSON and WOLFE, 1968).

Metalloendopeptidases are commonly produced by bacteria and fungi (Bergkvist, 1963; McConn et al., 1964; Hrramatsu, 1967a, b; Morihara et al., 1967, 1968; Narahashi et al., 1968; Day et al., 1968; Matsubara, 1970), but only rarely have they been isolated from invertebrate sources. Even in those few cases in which enzymes of this class have been detected in insects, their production by endosymbiotic microorganisms remains a very plausible possibility. A metalloendopeptidase has been detected in larvae of the webbing cloths moth, but endosymbiotic bacteria appear to be the most likely origin of this enzyme (WARD, 1972). An enzyme of this class is produced by a strain of Serratia which lives as an endosymbiont within the gut of the silkworm (Mryata et al., 1971). Metalloendopeptidase activity has also been detected in the sphingid moth Manduca sexta (BADE and Shoukimas, 1974) and possibly in the honey-bee (Giebel et al., 1971). 


\section{The origin of the faecal proteinases}

The results of this study strongly suggest that the proteolytic enzymes in the faecal material of $A$. texana are of microbial origin. This conclusion was quite unanticipated, since it had been our bias that these enzymes were probably digestive enzymes secreted in the midgut and concentrated in the rectum.

A priori it is possible to envision two plausible origins for these enzymes, microbial endosymbionts, and the fungus cultivated and consumed by the ants. There is ample precedent for the secretion of enzymes by symbiotic microorganisms living within the guts of insects, although the presence of endosymbionts in ants appears to be much less common than in some other families (JUNGEN, 1968). Likewise, the possibility that the enzymes are present in the fluid within the fungal hyphae upon which the ants feed, but are not secreted into the medium, is entirely plausible. Studies soon to be reported will clarify unambiguously the origin of these interesting enzymes.

Acknowledgements-We wish to thank the National Science Foundation for a grant (No. GB-31581) which supported this study. We also wish to thank Professor Jules SHafer, Department of Biological Chemistry, University of Michigan, for providing us with a number of substrates and for the use of his amino acid analyzer. We wish to express our appreciation to Dr JOAN S. MarTin for doing most of our dissections. Finally, we wish to thank Mr LARRY RotoN for his help in locating and excavating nests of Atta texana.

\section{REFERENCES}

ANDREWS P. (1964) Estimation of the molecular weights of proteins by Sephadex gelfiltration. Biochem. F. 91, 222-233.

Anson M. L. (1938) The estimation of pepsin, trypsin, papain and cathepsin with hemoglobin. F. gen. Physiol. 22, 79-89.

Applebaum S. W., Birk Y., Harpaz I., and Bondi A. (1964) Comparative studies on proteolytic enzymes of Tenebrio molitor L. Comp. Biochem. Physiol. 11, 85-103.

BADE M. L. and Shoukimas J. J. (1974) Neutral metal chelator-sensitive protease in insect moulting fluid. F. Insect Physiol. 20, 281-290.

BeLt T. (1874) The Naturalist in Nicaragua. John Murray, London.

Bergkvist R. (1963) The proteolytic enzymes of Aspergillus oryzae. I. Methods for the estimation and isolation of the proteolytic enzymes. Acta Chem. Scand. 17, 1521 1540.

Bongers J. and Nogge G. (1970) Unspezifische Esterase und Proteinase der Speicheldrusen und des Darmes von Hypoderma bovis. F. Insect Physiol. 16, 2127-2136.

Brookes V. J. (1963) Separation and characterization of proteolytic enzymes of Phormia regina. Fedn. Proc. 22, 528.

Cheung A. C. and Gooding R. H. (1971) A study of trypsin in Calasoma calium (Fab.) and Carabus taedatus Fab. Comp. Biochem. Physiol. 37, 331-338.

Davis B. J. (1964) Disc electrophoresis-II. Methods and application to human serum proteins. Ann. N.Y. Acad. Sci. 121, 404-427.

Day W. C., Toncic P., Stratman S.L., Leeman U., and Harmon S. R. (1968) Isolation and properties of an extracellular protease of Trichophyton granulosum. Biochim. biophys. Acta 167, 597-606.

ENSIGN J. C. and Wolfe R. S. (1965) Lysis of bacterial cell walls by an enzyme isolated from a Myxobacter. F. Bact. 90, 395-402.

FEDer J. and Lewis C. (1967) Studies on the specificity of Bacillus subtilis neutral protease with insulin B-chain. Biochem. biophys. Res. Commun. 28, 318-323. 
Felsted R. L., Law J. H., Sinha A. K., and Jolly M. S. (1973) Properties of the Antheraea mylitta cocoonase. Comp. Biochem. Physiol. 44B, 595-609.

FRATELlo B. (1968) Enhanced interpretation of tissue protease activity by use of photographic color film as a substrate. Stain Technol. 43, 125-128.

FreEman M. A. (1967) Proteolytic enzymes of the crop fluid from Locusta migratoria L. Comp. Biochem. Physiol. 20, 1013-1015.

Giebel W., Zwilling R., and Pfleiderer G. (1971) The evolution of endopeptidases-XII. The proteolytic enzymes of the honey-bee (Apis mellifica). Comp. Biochem. Physiol. 38B, 197-210.

Gooding R. H. and Huang C.-T. (1969) Trypsin and chymotrypsin from the beetle Pterostichus melanarius. F. Insect Physiol. 15, 325-340.

Green N. M. and Neurath H. (1953) The effects of divalent cations on trypsin. $\mathcal{F}$. biol. Chem. 204, 379-390.

Hagenmaier H. E. (1971) Purification and characterization of a trypsin-like proteinase from the midgut of the larvae of the hornet Vespa orientalis. F. Insect Physiol. 17, 1995-2004.

Heilman J., Barollier J., and Watzke E. (1957) Beitrage zur Aminosaurebestimmung auf Papierchromatogrammen. Hoppe-Seyler's Z. physiol. Chem. 309, 219-220.

Hiramatsu A. (1967a) A neutral proteinase from Streptomyces naraensis. I. Purification and some properties. F. Biochem (Tokyo) 62, 353-363.

Hiramatsu A. (1967b) A neutral proteinase from Streptomyces naraensis. II. Its mode of action on bakers' yeast cytochrome C. F. Biochem., Tokyo 62, 364-372.

Hruska J. F. and Law J. H. (1970) Cocoonases. In Methods of Enzymology (Ed by Perlmann G. E. and Lorand L.), 19, pp. 221-226. Academic Press, New York.

HUBER J. (1905) Über dei Koloniengründung bei Atta sexdens. Biol.Zbl. 25, 606-619, 625-635.

JACKSON R. L. and WoLfE R. S. (1968) Composition, properties, and substrate specificities of Myxobacter AL-1 protease. F. biol. Chem. 243, 879-888.

JungeN H. (1968) Endosymbionten bei Ameisen. Insectes Sociaux 15, 227-232.

Kafatos F. C., Tartakoff A. M., and Law J. H. (1967a) Cocoonase-I. Preliminary characterization of a proteolytic enzyme from silk moths. F. biol. Chem. 242, 1477-1487.

Kafatos F. C., Law J. H., and Tartakoff A. M. (1967b) Cocoonase-II. Substrate specificity, inhibitors, and classification of the enzyme. F. biol. Chem. 242, 1488-1494.

Katzenellenbogen B. S. and Kafatos F. (1971) Proteinases of silk moth moulting fluid: physical and catalytic properties. F. Insect Physiol. 17, 775-800.

KunItz M. (1947) Crystalline soybean trypsin inhibitor-II. General properties. $\mathcal{F}$. gen. Physiol. 30, 291-310.

LeCadet M.-M. and Dedonder R. (1966) Les protéases de Pieris brassicae-II. Spécificité. Bull. Soc. Chim. biol. 48, 661-691.

Lowry O. H., Rosebrovgh N. J., Farr A. L., and Randall R. J. (1951) Protein measurements with the Folin phenol reagent. F. biol. Chem. 193, 265-275.

Mahler H. R. and Cordes E. H. (1966) Biological Chemistry. Harper \& Row, New York.

Martin M. M., Gieselmann M. J., and Martin J. S. (1973) Rectal enzymes of attine ants. $\alpha$-Amylase and chitinase. $\mathscr{F}$. Insect Physiol. 19, 1409-1416.

MarTin J. S. and MarTin M. M. (1970a) The presence of protease activity in the rectal fluid of attine ants. F. Insect Physiol. 16, 228-232.

Martin M. M. and Martin J. S. (1970b) The biochemical basis for the symbiosis between the ant, Atta colombica tonsipes, and its food fungus. F. Insect Physiol. 16, 109-119.

Martin M. M. and Martin J. S. (1971) The presence of protease activity in the rectal fluid of primitive attine ants. F. Insect Physiol. 17, 1897-1906.

MarTin S. M., Singh K., ANKel H., and KahN A. H. (1962) Specificity of a protease from Penicillium cyaneofulvum. Can. F. Biochem. physiol. 40, 237-246.

Matsubara H., Sasaki R., Singer A., and Jukes T. H. (1966) Specific nature of hydrolysis of insulin and tobacco mosaic virus protein by thermolysin. Arch. Biochem. Biophys. 115, 324-331. 
Matsubara H. (1970) Purification and assay of thermolysin. In Methods in Enzymology (Ed by Perlmann G. E. and Lorand L.) 19, pp. 642-651. Academic Press, New York.

McConn J. D., Tsuru D., and YasunoBu K. T. (1964) Baccillus subtilis neutral proteinase I. A zinc enzyme of high specific activity. F. biol. Chem. 239, 3706-3715.

Millet J. and ARCHER R. (1969) Specificity of megateriopeptidase, an aminoendopeptidase of hydrophobic character. Eur. F. Biochem. 9, 456-462.

Miyata K., Tomoda K., and Isono M. (1971) Serratia protease III, Characteristics of the enzyme as metalloenzyme. Agric. Biol. Chem. 35, 460-467.

Moore S. and Stein W. H. (1958) Photometric ninhydrin method for use in the chromatography of amino acids. F. biol. Chem. 176, 367-388.

Morihara K., Oka T., and Tsuzuki H. (1967) Multiple proteolytic enzymes of Streptomyces fradiae. Production, isolation and preliminary characterization. Biochim. biophys. Acta 139, 382-397.

Morihara K., OKa T., and Tsuzuki H. (1968) Comparison of specificities of various neutral proteinases from microorganisms. Archs. Biochem. Biophys. 123, 572-588.

Morihara K. and Tsuzuki H. (1969) Comparison of the specificities of various serine proteinases from microorganisms. Arch. Biochem. Biophys. 129, 620-634.

Múller F. (1874) The habits of various insects. Nature, Lond. 10, 102-103.

Murachi T. and Neurath H. (1960) Fractionation and specificity studies on stem bromelain. 7. biol. Chem. 235, 99-107.

Narahashi Y., ShibuYa K., and Yanagita M. (1968) Studies on proteolytic enzymes (Pronase) of Streptomyces griseus K-1-2. Separation of exo-and endopeptidases of pronase. F. Biochem., Tokyo 64, 427-437.

Neurath H., Walsh K. A., and Winter W. P. (1967) Evolution of structure and function of proteases. Science, Wash. 158, 1638-1644.

Reisfeld R. A., Lewis U. J., and Williams D. E. (1962) Disk electrophoresis of basic proteins and peptides on polyacrylamide gels. Nature, Lond. 195, 281-283.

RIck W. (1963) Trypsin. Determination with casein as substrate. In Methods of Enzymatic Analysis (Ed. by Bergmeyer H. U.), pp. 811-814. Academic Press, New York.

Sanger F., Thompson E. O. P., and Kitai R. (1955) Amide groups of insulin. Biochem. . 59, 509-518.

Sonnenborn H.-H., Pfleiderer G., and Ishay J. (1969) Zur Evolution der EndopeptidasenVII. Eine Protease von Molekulargewicht 12,500 aus Larven von Vespa orientalis F. mit chymotryptischen Eigenschaften. Hoppe-Seyler's Z. physiol. Chem. 350, 389-395.

WARD C. W. (1972) Diversity of proteases in the keratinolytic larvae of the webbing clothes moth, Tineola bisselliella. Comp. Biochem. Physiol. 42B, 131-135.

WEBER K. and OsBoRn M. (1969) The reliability of molecular weight determinations by dodecyl sulphate-polyacrylamide gel electrophoresis. F. biol. Chem. 244, 4406-4412.

Weber N. A. (1972) Gardening ants, the Attines. Mem. Am. phil. Soc. 92, 1-146.

WheELER W. M. (1907) The fungus-growing ants of North America. Bull. Am. Mus, nat. Hist. 23, 669-807.

Yang Y. J. and Davies D. M. (1971a) Trypsin and chymotrypsin during metamorphosis in Aedes aegypti and properties of the chymotrypsin. F. Insect Physiol. 17, 117-131.

YANG Y. J. and Davies D. M. (1971b) Digestive enzymes in the excreta of Aedes aegypti larvae. F. Insect Physiol. 17, 2119-2123.

ZwilliNg R. (1968) Zur Evolution der Endopeptidasen-IV. $\alpha$-und $\beta$-Protease aus Tenebrio molitor. Hoppe-Seyler's Z. physiol. Chem. 349, 326-332. 